\title{
茶葉の熟度別抗酸化能の変化
}

\author{
独立行政法人 農業・生物系特定産業技術研究機構 野菜茶業研究所* \\ 木幡勝則・峰 伸一・氏原ともみ・堀江秀樹** \\ (平成15年 7 月31日受理)
}

\section{Changes in Anti-oxidative Activities during the Development of Tea Shoots}

\author{
Katsunori Kohata, Shinichi Mine, Tomomi Ujihara, Hideki Horie \\ National Institute of Vegetable and Tea Science \\ National Agricultural and Bio-oriented Research Organization
}

\section{Summary}

Changes in anti-oxidative activities of fresh tea and crude tea leaves were investigated by the discoloration of $\beta$-carotene coupled with the oxidation of linolic acid ( $\beta$-carotene anti-oxidative activity) and the scavenging activity of DPPH (1,1-Diphenyl-2-picrylhydrazyl) radical. Furthermore, relationship between the anti-oxidative activities and the contents of tea components were also investigated. The anti-oxidative activities decreased during the development of tea shoots. The decreasing rate of the $\beta$-carotene anti-oxidative activity approximately corresponded to that of ester typed catechins (EGCg $+\mathrm{ECg}$ ) or EGCg, suggesting that the changes in the anti-oxidative activities were more reflected on the $\beta$-carotene anti-oxidative activity. There was a strong relationship between the anti-oxidative activity and contents of ester-typed catechins, especially EGCg. This tendency wa enhanced by the addition of ascorbic acid (VC) to the contents of ester typed catechins or EGCg, but the contribution of $\mathrm{VC}$ to the relationship was relatively small.

Key Words : anti-oxidative activity, DPPH, $\beta$-carotene, tea leaves, catechins

\section{1. 緒言}

茶葉の抗酸化能に関しては，これまで数多 くの報告がなされている。その中で，カテキ ン類と抗酸化能との間に正の相関のあること や1), カテキン類の抗酸化能に対してアスコ
ルビン酸 (VC) が強い相乗効果を示すことが 明らかにされている2。

ところで，主要なカテキン類の総量は茶葉 の熟度が進むに従って減少することが知られ ているが3)，カテキン類について個々にみて みると,エステル型カテキン類 $(\mathrm{EGCg}+$

* T428-8501 静岡県漛原郡金谷町金谷2769

** 現 T514-2392 三重県安芸郡安濃町大字草生 360 
$\mathrm{ECg}$ )が減少するのに対し, 遊離型カテキン類 $(\mathrm{EGC}+\mathrm{EC})$ は増加するなど, 必ずしも増減 は一定ではない。一方, 通常よく用いられて いる抗酸化能測定法として, $\beta$-カロテンーリ ノール酸法)，大豆油またはラードを用いる 抗酸化能測定法"1), 1,1-Diphenyl-2-picrylhydrazyl(DPPH) ラジカル捕捉能測定法 ${ }^{5)}$ 等が 挙げられるが，これらの方法を用いてカテキ ン類の個々の抗酸化能を測定した結果では, 総じてエステル型カテキン類が遊離型カテキ ン類よりも強い抗酸化能を有することが報告 されている。

これらの事実から，茶葉の熟度が進むに伴 い抗酸化能も低下寸ることが予想されるが， これまで熟度と抗酸化能との相関について㭘 討した報告例はほとんど見当たらない。そこ で，本論文では茶葉の抗酸化能に及ぼす熟度 の影響をカテキン類およびVC含有量との相 関から検討したので報告する。

\section{2. 実 験 方 法}

\section{1 茶試料の調製}

生葉は, 品種としでやぶきた’を用い, 野菜 茶業研究所試験圃場（金谷）で2002年 4 月 15 日，18日，22日，25日および29日に枠摘みし た $(20 \mathrm{~cm} \times 20 \mathrm{~cm}, 5$ 反復, 出開度は, 順に 0 , $16,30,68,88 \%)$ 。次いで, 直ちに電子レン ジ $(500 \mathrm{~W})$ で 1 ～ 2 分ブランチング処理し, $70^{\circ} \mathrm{C}$ で一晚温風乾燥後, 粉砕したものを茶生 葉試料とした。

荒茶試料は，品種として‘やぶきた’を用い， 野菜茶業研究所試験围場（金谷）で2002年 4 月22日，23日，25日，5月 1 日および 7 日に 機械摘みし，通常の煎茶製造方法で製造した 煎茶の荒茶を粉砕して調製した。

\section{2 . $2 \beta$-カロテン退色法による抗酸化能}

$\beta$-カロテン退色法による抗酸化能（以後 $\beta$ 一カロテン抗酸化能と略す。）の測定法は, リ ノール酸の自動酸化に伴い生じるリノール酸 過酸化物が, $\beta$-カロテンの二重結合と反応す

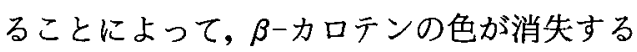
ことを利用した方法である ${ }^{6,7)}$ 。加えた試料の
抗酸化能が高いほどリノール酸の酸化が抑兄 られ， $\beta$-カロテンの退色が抑えられる。反応

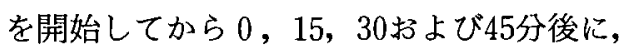
$\beta$-カロテンの吸収極大波長である $417 \mathrm{~nm} に$ おける吸光度（減少）を測定する。本法は, 比較的短時間に数点の試料の測定ができ, 簡 便な方法であり, 野菜等の抗酸化能の評価に もしばしば用いられていることから, 本論文 でも採用した。

抗酸化能は, 試料溶液における0分後の吸 光度から 30 分後の吸光度を引いた值(A)と, 抗 酸化剤であるBHA(3(2)-t-Butyl-4-hydroxy anisole, $1 \mathrm{mg} / 100 \mathrm{ml}$ ) 溶液における0 分後の 吸光度から 30 分後の吸光度を引いた值(B)か ら, $\mathrm{A} / \mathrm{B}(\%)$ で求めた。即ち, 試料の抗酸 化能の強さを $\mathrm{BHA}(1 \mathrm{mg} / 100 \mathrm{ml})$ を標準とし て表した值で，100\%であればBHAと同じ抗 酸化能ということになる。なお, 本論文では 30分後の值を用いたが, 15分後あるいは45分 後の値を用いてもよい。

試料の調製法は, 茶生葉および荒茶試料 各々 $3 \mathrm{~g}$ を耐熱ガラスポット（セレック V ポット, セレック侏製)に採り, 沸騰水 $200 \mathrm{ml}$ を加えて時々擋汼しながら 5 分間放置した。 抽出液をろ過してろ液を約 $20 \mathrm{ml}$ 採取し, 直ち に室温まで冷却後, 10 倍希积して試料液とし た。試料の調製は 3 連で行った。

\subsection{DPPHラジカル捕捉能の測定}

1,1-Diphenyl-2-picrylhydrazyl (DPPH) を用い, 試料を加えたときのDPPHの吸収極 大波長である517nmの吸光度変化を測定する 方法に従った ${ }^{8,9)}$ 。補足能が大きい程, 吸光度 の減少が大きくなる。本法は, DPPHが安定 なラジカルで取り扱いやすく, 消去能を簡便 に評価できることから，茶試料を初めとする 様々な試料に応用されており，本論文でも採 用した。捕捉能の値は, 抗酸化剤である Trolox (6-Hydroxy-2,5,7,8-tetramethylchroman-2-carboxylic acid)濃度相当量と して表した。試料の調製法は, $\beta$-カロテン抗 酸化能の測定法と同椂であるが, 希釈は20倍 とした。 
2.4 カテキン類およびVC測定

堀江らの方法 ${ }^{10)}$ に従い, 主要カテキン類 4 種 (EC, EGC, EGCg, ECg) およびVCを同時 定量した。試料の調製法は, $\beta$-カロテン抗酸 化能の場合と同じである。

\section{5 統計処理}

チューキーの多重比較より行った。

\section{3．実験結果と考察}

\section{$3 \therefore 1$ 茶生葉試料}

$\beta$-カロテン抗酸化能は, 熟度が進むにつれ て減少する傾向を示し，30分後の測定では， 最大で約 $30 \%$ 程度減少した（表 1)。

一方，DPPHラジカル補足能は，4月18日 に一端増加し，その後は減少する傾向にあっ たが，減少の大きさは最大で約 $10 \%$ 程度と $\beta$ 一カロテン抗酸化能と比較してそれ程大きく なかった（図 1)。

カテキン類含有量では，これまでに知られ ているように, 熟度が進むにつれて遊離型力 テキン類のEGCは増加したが，反対に，エス テル型カテキン類のEGCgおよびECgは減少 した。主要 4 種のカテキン類（以後主要カテ キン類と略す。)は摘採初期に増加し，その後 は減少する傾向にあったが，減少は最大で 10\%程度とそれ程大きくなかった(図 2 )。こ れは，摘採最終日(4月29日)の出開度 $(88 \%)$ が示すように，摘採期間が短か過ぎたためと 思われる。

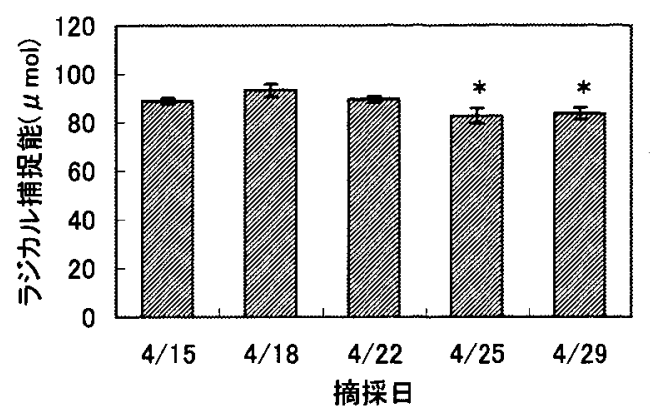

図 1 茶生葉試料における熟度別DPPH捕捉能 の变化

捕捉能は Trolox濃度 $(\mu \mathrm{mol})$ 相当量とし て表した。 4 月18日の值を基に，*は $5 \%$ で, **は $1 \%$ で有意差のあるものを示す。

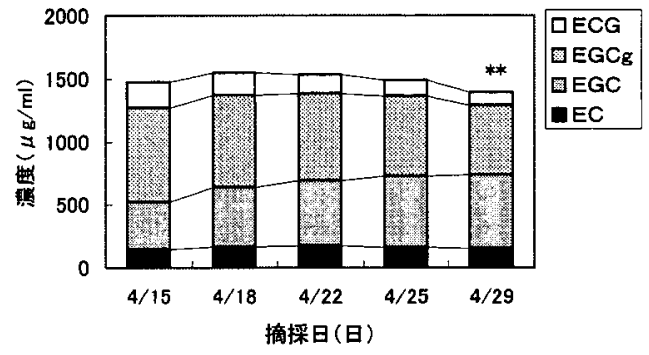

図 2 茶生葉試料における熟度別カテキン類含 有量の変化

4 月18日の値を基に, * で有意差のあるものを示す。

表 1 茶生葉および荒茶試料の熟度別 $\beta$ ーカロテン抗酸化能

\begin{tabular}{|c|c|c|c|}
\hline \multicolumn{4}{|c|}{ 抗酸化能 $(\%) \pm$ 標準偏差 ${ }^{a)}$} \\
\hline \multicolumn{2}{|c|}{ 茶生葉試料 } & \multicolumn{2}{|c|}{ 荒茶試料 } \\
\hline 4 月15日 & $89.08 \pm 8.88$ & 4 月 22 日 & $86.11 \pm 6.35$ \\
\hline 4 月18日 & $92.68 \pm 4.09$ & 4 月23日 & $66.45 \pm 3.50^{* *}$ \\
\hline 4 月 22 日 & $87.26 \pm 4.10$ & 4 月25日 & $65.14 \pm 5.25^{* *}$ \\
\hline 4 月25日 & $78.26 \pm 1.91^{*}$ & 5 月 1 日 & $39.95 \pm 5.85^{* *}$ \\
\hline 4月29日 & $62.69 \pm 4.46^{* *}$ & 5月7日 & $32.74 \pm 5.31^{* *}$ \\
\hline
\end{tabular}

a )

試料溶液 0 分の吸光度 -30 分後の吸光度) $\times 100$

(BHA ( $1 \mathrm{mg} / 100 \mathrm{ml}) 0$ 分後の吸光度 -30 分後の吸光度)

生葉試料は 4 月 15 日, 荒茶試料は 4 月 22 日の抗酸化能を基に, *は $5 \%$ で, **は $1 \%$ で有意差のあるもの を示す。 
VC含有量は，摘採初期には增加し，4月 22 日の中期に扔いて最大に達した後, 徐々に減 少した(図 3)。この結果は，これまでに報告 されてる結果と異ならない11)。最初の摘採日 である 4 月15日の值が著しく低くなったの は，摘採した芽が若過ぎたことに起因してい るものと考えられる。

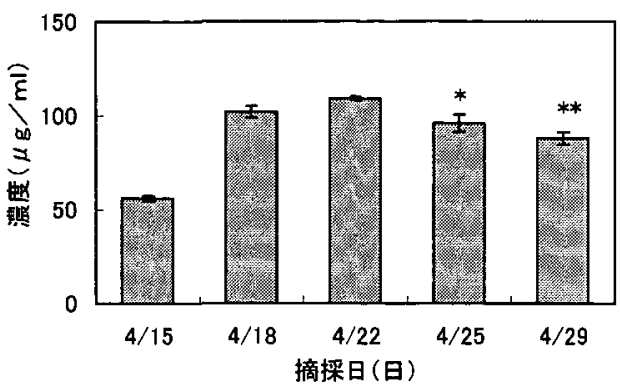

図 3 茶生葉試料における熟度別アスコルビン 酸含有量の変化

4 月18日の值を基に, *は $5 \%$ で，**は $1 \%$ で有意差のあるものを示す。

成分含有量と $\beta$-カロテン抗酸化能との相

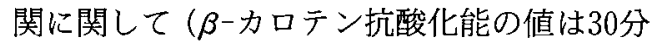
における測定値を用いた)，VCとの間には相 関は認められなかったものの, 主要カテキン 類との間には比較的強い正の相関が認められ

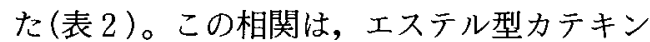
類に限定すればさらに強くなり，EGCgに限 定すればさらに強くなった。加えて, エステ
ル型カテキン類およびEGCgにVCを加えれ ばさらに強くなることが明らかとなった。

成分含有量とDPPHラジカル補足能との 間の相関では, $\beta$-カロテン抗酸化能における 結果と同様に, $\mathrm{VC}$ と間には相関は認められ なかったが，主要カテキン類との間には弱い ながら正の相関が認められた(表 2)。この相 関は，エステル型カテキン類に限定すればさ らに強くなり，EGCgに限定すればさらに強 くなった。加えて, エステル型カテキン類お よびEGCgにVCを加えればさらに強くなる ことが明らかとなった。

$\beta$-カロテン抗酸化能とDPPHラジカル捕 捉能は, 熟度が進むに従い減少することが明 らかとなったが, 減少は前者で最大 $30 \%$ 程度, 後者で $9 \%$ 程度であった。エステル型力テキ ン類およびEGCgの減少割合（約30\%）を考慮 すると, 熟度の変化は $\beta$-カロテン抗酸化能の 上に,より強く反映されるものと考察される。

一般に, 油脂の抗酸化能に関してはEGCg が最も強いとされているが1, 成分含有量と $\beta$ 一カロテン抗酸化能およびDPPHラジカル捕 捉能との相関に㧧いて，エステル型カテキン 類との間に強い正の相関が認められたこと， 特に, EGCgとの間に強い正の相関が認めら れたことは，これまでの結果と矛盾しない。

VCが抗酸化能との間にほとんど相関を示 さなかったのは，4月15日の含有量が非常に 低かったためと考えられる。この值を除いた

表 2 成分含有量と抗酸化能との相関

\begin{tabular}{|c|c|c|c|c|}
\hline & \multicolumn{2}{|c|}{$\begin{array}{c}\beta-\text { 抗酸化能 } \\
\left(\mathrm{R}^{2}\right)\end{array}$} & \multicolumn{2}{|c|}{$\begin{array}{c}\text { DPPH捕捉能 } \\
\left(\mathrm{R}^{2}\right) \\
\end{array}$} \\
\hline & 茶生葉 & 荒 茶 & 茶生茶 & 荒 茶 \\
\hline $\mathrm{EGC}+\mathrm{EC}+\mathrm{EGCg}+\mathrm{ECg}$ & 0.807 & 0.179 & 0.524 & 0.607 \\
\hline $\mathrm{VC}$ & - & 0.513 & 0.015 & 0.763 \\
\hline $\mathrm{EGC}+\mathrm{EC}$ & $0.433^{*}$ & $0.582^{*}$ & $0.316^{*}$ & $0.180^{*}$ \\
\hline $\mathrm{EGCg}+\mathrm{ECg}$ & 0.894 & 0.917 & 0.621 & 0.939 \\
\hline $\mathrm{EGCg}+\mathrm{ECg}+\mathrm{VC}$ & 0.970 & 0.913 & 0.709 & 0.947 \\
\hline $\mathrm{EGCg}$ & 0.947 & 0.905 & 0.645 & 0.955 \\
\hline $\mathrm{EGCg}+\mathrm{VC}$ & 0.995 & 0.900 & 0.730 & 0.955 \\
\hline
\end{tabular}

$\mathrm{R}^{2}$ ：相関係数； $\mathrm{VC} ：$ アスコルビン酸； *：負の相関 
ときの相関係数 $\left(\mathrm{R}^{2}\right)$ が, $\beta$-カロテン抗酸化 能では0.769, DPPHラジカル捕捉能では 0.509まで高くなることからもこの考察は指 示される。すなわち, VCと抗酸化能との相関 は弱いながら認められたといえる。

\section{2 荒茶試料}

$\beta$-カロテン抗酸化能は, 茶生葉試料と同様 に、熟度が進むにつれて減少する傾向を示し たが，30分後の測定では最大で約60\%程度減 少し，生葉試料より減少の割合がかなり大き いことがわかった（表 1 ）。

DPPHラジカル補足能は, 茶生葉試料と同 様に, 熟度が進むにつれて減少する傾向を示 したが, 減少割合は最大で約 $13 \%$ と生葉試料 よりいく分大きい程度であった（図 4)。

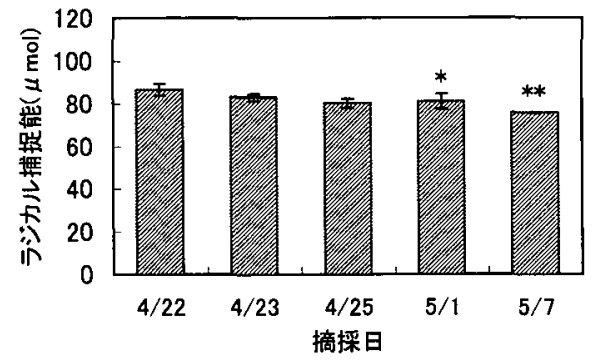

図 4 荒茶試料における熟度別DPPH捕捉能の 变化

捕捉能はTrolox濃度 $(\mu \mathrm{mol})$ 相当量とし て表した。4月22日の值を基に，*は $5 \%$ で, **は1\%で有意差のあるものを示す。

カテキン類含有量の変化では, 生葉試料と 同椂に，5月 1 日を除いて熟度が進むにつれ てEGCは増加したが, 反対に, エステル型力 テキン類のEGCg预よびECgは減少した。全 カテキン類は，5月1日を除いて徐々に減少 する傾向にあり，最大で約 $13 \%$ 減少した。 5 月 1 日の突出した増加はEGCの増加に由来 するものであるが，この原因については今の ところわかってない（図 5 )。

$\mathrm{VC}$ 含有量の変化は, 茶生葉同様初めに増加 した後, 徐々に減少する傾向にあり, 減少割

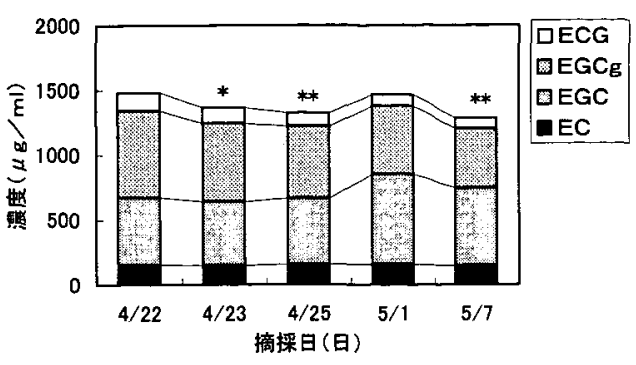

図 5 荒茶試料における熟度別カテキン類含有 量の変化

4 月22日の值を基に, *は $5 \%$ で, **は 1\% で有意差のあるものを示す。

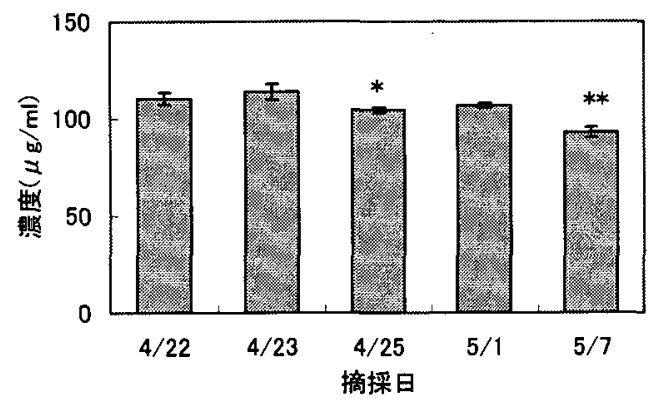

図 6 荒茶試料における熟度別アスコルビン酸 含有量の変化

4 月22日の值を基に, *は $5 \%$ で,** $1 \%$ で有意差のあるものを示す。

合は最大で約 $18 \%$ であった（図 6 )。

成分含有量と $\beta$-カロテン抗酸化能との相 関では, VCとの閒には弱いながら正の相関が 認められたが, 主要カテキン類含有量との間 には相関は認められなかった。エステル型カ テキン類およびEGCgとの間には生葉試料同 様に強い正の相関が認められた(表 2)。しか し, 茶生葉試料に見られたような, $\mathrm{EGCgに}$ 定寸ることによる効果の向上やVCを加える ことによる効果の向上はほとんど認められな かった。

成分含有量とDPPHラジカル補足能との 間の相関では, $\mathrm{VC}$ よび主要カテキン類含有 量との間には正の相関が認められた。主要カ テキン類含有量との相関は, エステル型カテ キン類やEGCgに限定すればさらに強くなる 
ことが明らかとなったが， $\beta$-カロテン抗酸化 能の場合と同様に，EGCgに限定することに よる効果の向上やVCを加えることによる効 果の向上はほとんど認められなかった。

VCは, カテキン類の抗酸化能に対して強い 相乗効果を示すことが知られているが2)，そ の時のVCはカテキン類と同程度か, 10倍濃い 濃度であった。本論文での実験条件下では, VCは全カテキン類の1/15程度しか含まれて おらず，このことが茶生葉および荒茶試料の 双方に扔いても強い相乗効果を示さなかった 要因と推察される。

以上, 熟度が増すと抗酸化能は減少するが, それはエステル型カテキン類, 中でも $\mathrm{EGCg}$ の隇少によるところが大きく, VCも一部は関 与していることが明らかとなった。茶生葉お よび荒茶試料で得られた結果が大筋で一致し ていたことから，一番茶期における茶葉の熟 度別抗酸化能の変化が, 概ね明らかにされた ものと思われる。

\section{4. 摘要}

(1) $\beta$-カロテン抗酸化能とDPPHラジカル捕捉能 は, 熟度が進むに従い減少することが明らか となった。減少は前者で最大 $30 〜 60 \%$ 程度， 後者で10～13\%程度で, エステル型カテキン 類およびEGCgの減少割合 (約30\%) を考慮 すると, 熟度の変化は $\beta$-カロテン抗酸化能 により強く反映されるものと考察される。

(2) $\beta$-カロテン抗酸化能とDPPHラジカル補足能 との強い正の相関は, 主要カテキン類よりも エステル型カテキン類,特にEGCgとの間に あることが明らかとなった。この相関は, エ ステル型カテキン類やEGCgにVCを加えるこ とでわずかながら強くなる傾向にあった。し かし，VCの抗酸化能に及ほす影響は，その 含有量が主要力テキン類と比較して $1 / 15$ 程度 と少ないことから, 小さいか, あってもそれ 程大きいとはいえなかった。

\section{5. 引用文 献}

1) 原征彦 (1955)：茶の抗酸化作用, 村松敬一 郎編, 茶の科学, 朝倉書店, 東京, pp. 124-131.

2) 松崎妙子・原征彦(1985)：茶葉カテキン類 の抗酸化作用について,農化, 59, 129-134.

3 ) 吉田優子・木曽雅昭・長島等・後藤哲久 (1996）：茶芽の生育に伴う化学成分含量の 変化，茶研報， No.83，9-16.

4) Amarowicz, R. and F. Shahidi (1995): Antioxidant activity of green tea catechins in $\beta$-carotene-linoleate model system, J. Food Lipids, 2, 47.

5 ) Chen, C,-W. and C.-T. Ho (1995): Antioxidant properties of polyphenols extracted from green and black teas, J. Food Lipids, 2, 35.

6）農林水産省農林水産技術会議事務局・食品 総合研究所：食品の機能性評価マニュアル 集, pp. 23(1999).

7) 津志田藤二郎・鈴木雅博・黒木柾吉 （1994）：各種野菜類の抗酸化性の評価およ び数種の抗酸化成分の同定, 日食工誌, 41 , 611-618.

8）農林水産省農林水産技術会議事務局・食品 総合研究所：食品の機能性評価マニュアル 集, pp. 19-20(1999).

9) Yamaguchi, T., H.Takamura, T. Matoba and J. Terao(1988) : HPLC method for evaluation of the free radical -scavenging activity of foods by using 1 , 1-diphenyl-2-picrylhydrazyl, Bioci. Biotechnol. Biochem., 62, 1201-1204.

10）堀江秀樹・山本 (前田)万里・氏原ともみ・ 木幡勝則 (2003) : 茶葉中カテキン類分析の ための抽出方法の検討, 茶研報, №.94, 60-64.

11）高柳博次・阿南豊正 - 池ヶ谷賢次郎・中川 致之(1985): 茶芽の熟度と成分変動, 茶研 報，№.61，20-25. 